\title{
Indirect Financial Distress Costs: Evidence from Shariah- Compliant Firms in Malaysia
}

Norhisam Bulot, Abdul Hafiz Yusof, Nor Arni Nazira Othman \& Noor Hafizha Muhamad Yusuf

To Link this Article: http://dx.doi.org/10.6007/IJARBSS/v11-i11/11353

DOI:10.6007/IJARBSS/v11-i11/11353

Received: 21 September 2021, Revised: 24 October 2021, Accepted: 10 November 2021

Published Online: 25 November 2021

In-Text Citation: (Bulot et al., 2021)

To Cite this Article: Bulot, N., Yusof, A. H., Othman, N. A. N., \& Yusuf, N. H. M. (2021). Indirect Financial Distress Costs: Evidence from Shariah-Compliant Firms in Malaysia. International Journal of Academic Research in Business and Social Sciences, 11(11), 1493-1502.

\section{Copyright: (c) 2021 The Author(s)}

Published by Human Resource Management Academic Research Society (www.hrmars.com)

This article is published under the Creative Commons Attribution (CC BY 4.0) license. Anyone may reproduce, distribute, translate and create derivative works of this article (for both commercial and non0-commercial purposes), subject to full attribution to the original publication and authors. The full terms of this license may be seen at: http://creativecommons.org/licences/by/4.0/legalcode

Vol. 11, No. 11, 2021, Pg. 1493 - 1502

Full Terms \& Conditions of access and use can be found at http://hrmars.com/index.php/pages/detail/publication-ethics 


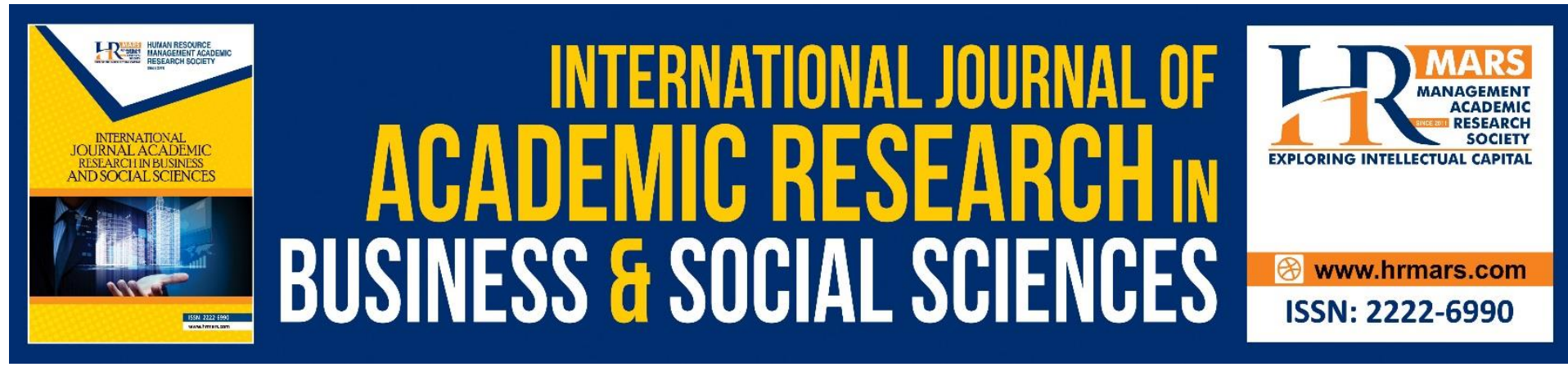

\title{
Indirect Financial Distress Costs: Evidence from Shariah-Compliant Firms in Malaysia
}

\author{
Norhisam Bulot, Abdul Hafiz Yusof, Nor Arni Nazira Othman \& \\ Noor Hafizha Muhamad Yusuf
}

Faculty of Business and Management Universiti Teknologi MARA Perlis Branch Arau Campus, 02600 Malaysia

\begin{abstract}
The main objective of this paper is to provide new empirical evidence on the size and determinants of the indirect financial distress costs for Malaysia's financially distressed firms. The use data from non-financial shariah-compliant financially distressed firms is the unique contribution of this paper. The analysis used the opportunity costs as the proxy for indirect financial distress cost. The population for this research is all shariah-compliant firms classified as financially distressed under the requirement of Practice Note 17 of Bursa Malaysia. The overall sample consists of 341 observations. The average size of the cost for the period of study is $13.41 \%$, and it ranges from a minimum value of $-241.43 \%$ to a maximum value of $111.76 \%$, indicates the existence of both cost and benefit of financial distress. The regression result suggests that the model fits the data well at the 0.05 significance level. The results of the regression also suggest firm size is the only independent variable was found to have a statistically significant relationship with the dependent variable, whereas change in investment policy, time in distress and leverage do not appear to be significantly related to the level of indirect financial distress cost.
\end{abstract}

Keywords: Capital Structure, Financial Distress, Firm Performance, Variable Selection Technique, Bankruptcy Costs.

\section{Introduction}

Indirect costs of financial distress (CFD), which is considered as opportunity costs (Warner 1977), refer to the costs suffered by a firm as a result of its deteriorating financial position (Elali \& Trainor 2008). Financial distress costs were found to be a significant factor for many financing decisions, such as corporate hedging practices and trade receivable policy. Current literature related to the size and influencing factors affecting financial distress costs is very limited. Several studies (see for example Andrade \& Kaplan, 1998; Korteweg, 2007; Pindado \& Rodrigues, 2005; Wijantini, 2007; Zhang \& Gan, 2010) have examined the variation in firms' financial distress costs to determine which variables are important in influencing the magnitude of financial distress costs. This research paper is enriched by considering both static and dynamic models of panel data instead of either one as found in many previous studies. In addition to that, this paper is novel and original given the fact there was no study conducted specifically for shariah-compliant financially distressed firms. Our study is 
therefore, aiming to fill this gap. In this paper, we argue that the findings would be different due to its unique firms (shariah-compliant) and legal characteristics.

\section{Literature Review}

\section{Determinants of indirect financial distress costs}

Time in Distress (TID): Previous studies suggest that time in distress has a positive association with the CFD. The basic argument is that time in distress relates to the CFD because the claimants might expand the company's resources over the time. The quicker the problems of a distressed firm are resolved; the value of the firm will be better. This is further supported by the research by Gertner \& Scharfstein and Giammarino (1991), which suggests that bargaining and coordination problems may slow down the restructuring process, and hence resulting in a higher CFD.

Leverage (LEV): Leverage continues to be one of the most important explanatory variables in explaining CFD. There are, however, opposing arguments for either positive or negative relation between leverage and CFD. Modigliani \& Miller (1958) and Modigliani \& Miller (1963); Opler \& Titman (1993) suggested that there is a positive relationship between leverage and CFD. give evidence that there is a positive relationship between financial structure and firm performance in industry downturns. They reveal that more highly leveraged companies tend to lose market share and experience lower operating profits than their competitors in industry downturns. This indirectly suggests a positive relationship between leverage and loss of market shares since one measurement of financial distress costs is by calculating the changes in corporate performance. Jensen and Wruck (1991) offer a different perspective of the problem in which not only the costs, but also the potential benefits of debt for financial distress processes are considered, implying that the benefits of leverage will reduce CFD.

Change in Investment Policy (CINV): As financial distress turns more serious and the probability of bankruptcy rises, the way in which firms react to the crisis must also be taken into consideration. The eventual recovery or bankruptcy of the firm will be the results of the firm's reaction and the financial distress costs it bears. In this context, this paper has selected the changes in investment policies as responses to financial distress, which will have an impact on the current performance of the firm. Asquith et al (1994) and Opler and Titman (1994) recognize that firms investment policy is affected during a financial crisis. Tshitangano (2010) shows that there is a negative relationship between change in investment policy and the size of indirect financial distress costs. Hence, this paper posits the third hypothesis as: Change in investment policy is negatively related to the indirect financial distress costs.

Investment Opportunity (IO): In this study, the existence of investment opportunity is proxied by Tobin's Q. Significance of the Tobin's Q coefficient would support the need to control for investment opportunities when explaining financial distress costs. The idea is that if a firm has good investment opportunities in comparison to its sector, this could mitigate the financial distress costs borne by the firm. Lang et al (1996) found a strong positive relationship between Tobin's $Q$ and all proxies for a firm's growth, and Pindado and De la Torre (2003) show that Tobin's $Q$ is better suited than book-to-market ratio to proxy for investment opportunities. These leading this paper to anticipate that a firm's investment opportunities will influence its expected sales growth.

Intangible Assets (INTANG): Firms with high asset intangibility usually have values in trademark, expertise, patents, rights, brand names, good reputations, and services after sales. In addition to that, the products of these firms will usually be priced relatively higher. That is, 
customers must pay higher prices for products or services provided by high asset intangible firms. As a result of financial distress, customers of high asset intangibility will become more hesitant to buy its products. Therefore, it is common to believe that when a firm is in financial distress, the more intangible the firm's assets, the higher the sales loss.

Tangible Assets (TANG): Financial contracts are strongly influenced by the degree to which a company's assets support the transactions with some form of collateral normally being essential to gaining access to credit. Thus, the proportion of tangible fixed assets in total company assets is a measure of the capacity to provide collateral and consequently obtain (re)financing. Nevertheless, these assets suffer a big loss of value when small companies go into distress because they will often negotiate in adverse market conditions. Shleifer \& Vishny (1992) point out that in recessions many potential buyers of a company's assets only buy when there is a big discount. Thus, sellers of a distressed company try to postpone transactions until markets become more liquid. Therefore, the higher the percentage of tangibles fixed assets over the total assets, the incentive will be smaller for the different stakeholders to push the firm into bankruptcy. As a result, this research posits the sixth hypothesis as: there is a significant negative relationship between tangible assets and indirect financial distress costs.

Holding of Liquid Assets (LA): The cash component of the assets is utilized by the firm to assist them in mitigating the effect of financial distress. Pindado \& Rodrigues find that the holding of liquid assets are negatively related to the costs of financial distress which implies that insolvent firms can take advantage of holding larger stocks of this kind of assets. Hence, this paper posits the seventh hypothesis as: there is a significant positive relationship between liquid assets and indirect financial distress costs.

Expected earnings growths (EEG): Firms with high expected earnings growth are considered susceptible to greater loses in distress. This is because a significant of their operating value depends on unrealized high future earnings. In times of distress, these relatively large components of value are lost. In addition, consistent with debt overhang problem, industries with large growth opportunities tend to have high potential costs of financial distress.

Size (SIZE): In theory, small firms have a bigger problem in assessing capital because of the asymmetric information between insiders and outsiders. The difficulties become severe when the possibility of liquidation arises. However, managing large firms during the period of financial distress maybe costly since its more complicated internal organizations require implicit contracts which may be difficult to enforce during difficult times. Bigger size may represent higher level and more complex conflicts of interest, making it more difficult for the claimants to agree over resolving the distress. Moreover, bigger firms may positively relate to larger number of creditors and bigger bank loans received by distressed firms. Given the possibility of higher conflicts in distress resolution as the number of creditors increases, the following hypothesis is tested: there is a significant positive relationship between size and the indirect financial distress costs.

\section{Methodology}

\section{Population and Sample}

The target population of the research was all shariah-compliant firms listed as financially distressed by Bursa Malaysia under the requirement of Practice Note 17 of Bursa Malaysia. 


\section{Model Specification}

To achieve the second objective of this research, a model was developed in which indirect financial distress costs were determined by a set of firm-specific variables that, according to financial theory and literature, will explain the size of indirect financial distress costs.

General specification model:

$F D C_{i t}=\beta_{0}+\beta_{1}$TID $_{i t}+\beta_{2} L_{E V} V_{i t}+\beta_{3} C I N V_{i t}+\beta_{4} I O_{i t}+\beta_{5} I N T A N G_{i t}+\beta_{6} T_{A N G_{i t}}+\beta_{7} L A_{i t}+\beta_{8} E G_{i t}+$ $\beta_{9} S I Z E_{i t}+\varepsilon_{i t}(1)$

Where:

$\mathrm{FDC}_{\text {it }} \quad=$ Indirect financial distress costs

$\beta_{1}$ TID $_{\text {it }} \quad=$ Time period in distress

$\beta_{2} \mathrm{LEV}_{\text {it }} \quad=$ Leverage

$\beta_{3} \mathrm{CINV}_{\text {it }} \quad=$ Change in investment policy

$\beta_{4} \mid O_{i t} \quad=$ Investment opportunities

$\beta_{5}$ INTANG $_{i t} \quad=$ Intangible assets

$\beta_{6}$ TANG $_{i t} \quad=$ Tangible assets

$\beta_{7} \mathrm{LA}_{\text {it }} \quad=$ Liquid Assets

$\beta_{8} E_{E} G_{i t} \quad=$ Expected earnings growth

$\beta_{9} \mathrm{SIZE}_{\mathrm{i}} \quad=$ Firm size

$\varepsilon_{\text {it }} \quad=$ Error term

\section{Data Analysis Steps}

The econometric model of indirect financial distress costs as presented in equation (1) is estimated by using panel data analysis steps as illustrated in Figure 1.

The first step is to determine the most optimal combination of predictors. In this study, Stata command, Vselect, developed by Lindsey and Sheather (2010) was used to determine whether certain variable should be included in the model. Generally, higher variance explained by the model R2ADJ and lower C, AIC, AICC and BIC values indicate the best fitting model (Lindsey \& Sheather, 2010). Similar Stata command, vselect, was also used by previous researchers from various fields of studies (Anwar \& Sun, 2012; Butler, Keefe, \& Kieschnick, 2014; Makumi, 2013; Mehrara \& Mohammadian, 2015).

The second step is to choose the most appropriate panel data estimator. The two available alternatives for analysing short panel data are static and dynamic techniques. In this paper, the main criterion for choosing between the two alternatives is by looking at the coefficient of the lagged dependent variable. The significance of the lagged dependent variable ( $p$-value $<0.05$ ) will indicate the need to go for dynamic model, as it (dynamic model) is more appropriate and useful when the dependent variable depends on its own past realizations (Brañas-Garza et al., 2011), otherwise static model is to be preferred ( $p$-value > 0.05).

The third step is to choose the most appropriate static or dynamic panel data analysis technique. The choice of the most appropriate static technique depends upon three types of tests as suggested and outlined by Park (2011). The tests are F-test, Breusch-Pagan Lagrange Multiplier (LM) test, and Hausman test. For dynamic model, System Generalized Method of Moment (SGMM) is preferred against Difference Generalized Method of Moment (DGMM). This is consistent with the previous literature that SGMM is better (Blundell \& Bond, 1998) and more efficient (Ahn \& Schmidt, 1995) than DGMM. 
The fourth and final step is to perform the diagnostic tests and to find the correct strategy to rectify the problem(s) identified (if any). The strategy to rectify the problem(s) will be based on the suggestion by Hoechle (2007).

Figure 1 Data Analysis Steps

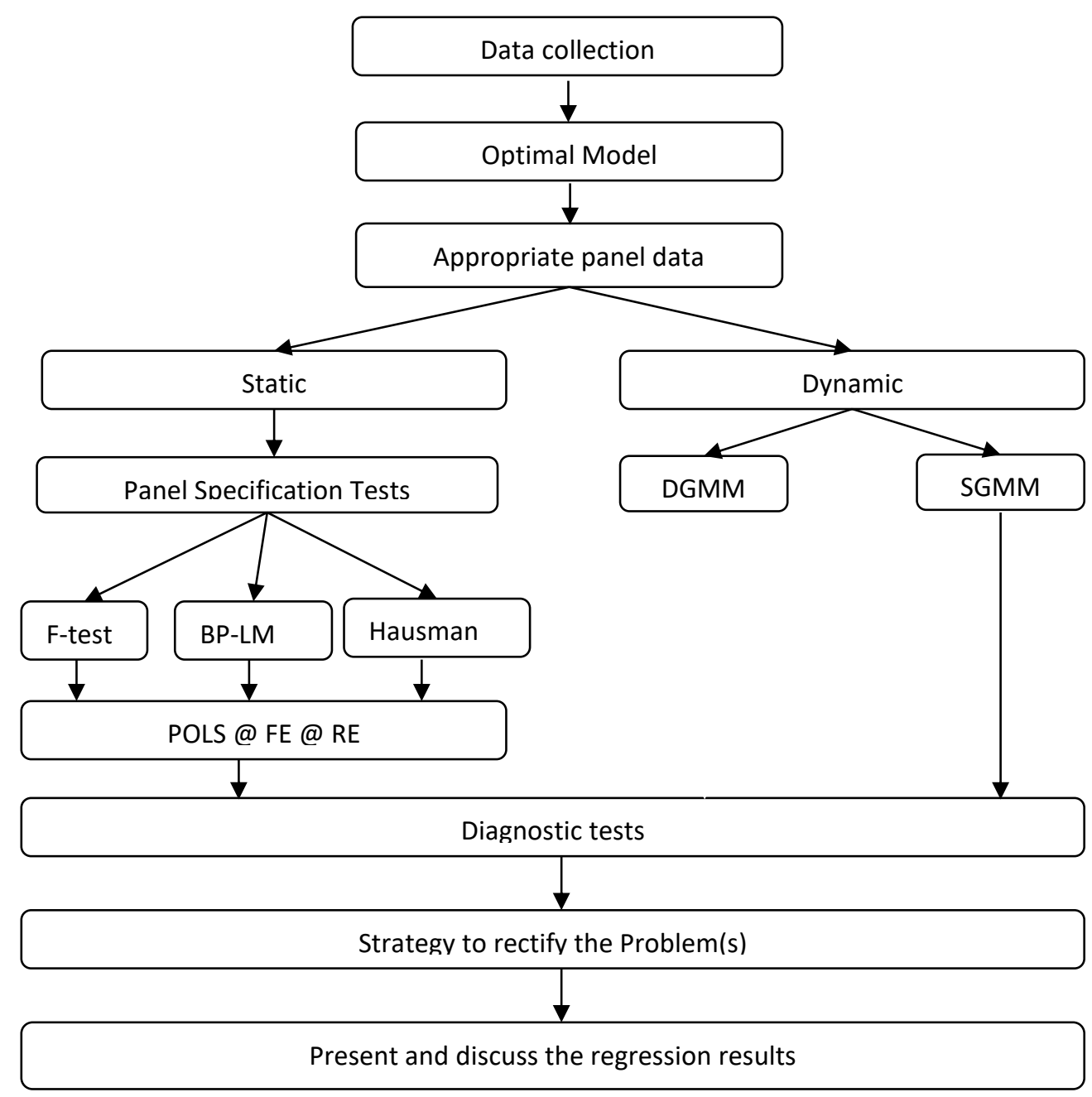

\section{Findings and Discussion}

The summary statistics and trend of the dependent variable over the sample period are presented in Table 3 and Table 4. Table 3 indicates that the average size of the indirect financial distress costs for the period of study is $23.43 \%$, and it ranges from a minimum value of $-450.70 \%$ to a maximum value of $113.52 \%$. This signifies the existence of both costs and benefits of financial distress. Table 4 shows the average size of the cost increased from only 0.54 (year -5) to 29.01 (year -1 ), as it came closer to financial distress.

Table 1: Descriptive Statistics

\begin{tabular}{llllll}
\hline \hline $\mathrm{N}$ & Mean & $\mathrm{SD}$ & Median & Min & Max \\
\hline 341 & 23.43 & 58.25 & 26.58 & -450.7 & 113.52 \\
\hline \hline
\end{tabular}


Table 2: Trend Analysis

\begin{tabular}{llllll}
\hline \hline Year & -5 & -4 & -3 & -2 & -1 \\
\hline Mean & -0.54 & 16.09 & 17.29 & 22.3 & 29.01 \\
\hline \hline
\end{tabular}

The first step is to determine the most optimal combination of predictors. As shown in Table 4.7 (Model 1), the choices of the most optimal model predictor sizes were seven for R2ADJ, five for C, AIC and AICC, and two for BIC. In this case, following the discussion in Section 3.9.1, the five-predictor model is chosen. The chosen variables are firm size, intangible assets, change in investment policy, leverage, and time in distress.

Table 3: Variable Selection

\begin{tabular}{lllllll}
\hline \hline R2ADJ & C & AIC & AICC & BIC & $\#$ & Predictors \\
\hline 7 & 5 & 5 & 5 & 2 & 5 & SIZE INTANG CINV LEV TID \\
\hline \hline
\end{tabular}

Notes: $C=$ Mallow's $C_{p}, \mathrm{R} 2 \mathrm{ADJ}=$ Adjusted $\mathrm{R}^{2}, \mathrm{AIC}=$ Akaike's information criterion, $\mathrm{AICC}=$ Akaike's corrected information criterion, $\mathrm{BIC}=$ Bayesian information criterion.

The next step is to choose the most appropriate panel data estimator. As shown in Table 6 , the coefficient for the lagged dependent variable is not significant ( $p$-value $>0.05$ ), therefore, a static model is more appropriate. The next decision to made is to decide which static panel approach to apply. As presented in Table 6, the results of the F-test (p-value < $0.05)$, BP-LM test $(p$-value $>0.05)$ and Hausman test ( $p$-value $<0.05)$ suggest that fixed effect is the most appropriate model estimator. Therefore, for the subsequent section, the analysis and discussion on the firm-specific determinants of indirect financial distress costs is based on the results of fixed effect model.

Table 4: Panel Specification Tests

\begin{tabular}{lllll}
\hline \hline \multicolumn{2}{l}{$p$-values of the tests } & & & \\
\hline \hline Lagged DV & F-test & BP-LM & Hausman & Technique \\
\hline 0.4780 & 0.0056 & 0.2111 & 0.0000 & Fixed Effect \\
\hline \hline
\end{tabular}

Once the appropriate model was determined, various diagnostic tests were then performed to check for the presence of multicollinearity, heteroskedasticity and serial correlation problems. As presented in Table 7, the diagnostic checks on the baseline model (FE) indicated the presence of heteroskedasticity ( $p$-value $<0.05)$ and serial correlation ( $p$-value $<0.05$ ) problems. To rectify the problems, following the suggestion by Hoechle (2007), remedial procedure has been carried out using fixed effect (within) regression with cluster option.

Table 5: Diagnostic Tests

\begin{tabular}{llll}
\hline \multicolumn{2}{l}{$\mathrm{p}$-values of the tests } & \multicolumn{2}{l}{} \\
\hline \hline VIF & $\mathrm{H}$ & $\mathrm{SC}$ & Strategy to rectify the problems \\
\hline 1.45 & 0.0000 & 0.0000 & FE (within) regression with cluster option \\
\hline \hline
\end{tabular}

Notes: VIF = Variance Inflation Factors; $\mathrm{H}=$ Heteroskedasticity; $\mathrm{SC}=$ Serial Correlation

Considering the various diagnostic tests that have been conducted and the remedial procedure undertaken, this paper may say that there is enough evidence to conclude that the examined statistical test satisfies the key assumptions of linear regression. As shown in Table 8 , the regression result suggests that the model fits the data well at the 0.05 significance level. The Adjusted $\mathrm{R}^{2}$ of 0.26 suggests that the five independent variables explain $26 \%$ of the variance in the indirect financial distress costs. The remaining $74 \%$ is explained by other 
variables that were not included in this model. The results of the regression also suggest that firm size and the level of intangible assets to have a statistically significant relationship with the dependent variable. Firm size and intangible assets are negatively related to the opportunity costs, whereas change in investment policy, leverage and time in distress do not appear to be significantly related to the opportunity costs. In addition to that, firm size seems to have the greatest influence on the level of indirect financial distress costs, which is explained by the highest $t$-value of -4.85 .

Table 6: Regression Result

Opportunity Costs as Dependent Variable

\begin{tabular}{ll}
\hline SIZE & $-23.06^{* * *}$ \\
& $(-4.85)$ \\
INTANG & $-0.02^{*}$ \\
& $(-1.68)$ \\
CINV & 0.00 \\
& $(0.08)$ \\
TID & $\cdot$ \\
& - \\
LEV & -0.02 \\
& $(-0.52)$ \\
Constant & $120.20^{* * *}$ \\
& $(6.54)$ \\
\hline $\mathrm{N}$ & 324 \\
$\mathrm{R}^{2}$ & 0.42 \\
$\mathrm{R}^{2}$ a & 0.26 \\
$\mathrm{~F}$ & 16.31 \\
$\mathrm{p}$-value & 0.00 \\
\hline
\end{tabular}

Notes:

(1) $t$ statistics in parentheses

(2) * $p<0.1, * * p<0.05, * * * p<0.01$

(3) TID = time in distress, LEV = leverage, CINV = change in investment, INTANG = intangible assets, and SIZE = firm size.

(4) $N$ = number of observations, $R^{2}=R$-squared, $R^{2} \_a=$ adjusted R-squared

\section{Conclusion}

The purpose of this study is to investigate the role of firm specific variables on the size of indirect financial distress costs. This research contributes to the literature for emerging market, especially Malaysia by providing the estimates of indirect financial distress costs and by developing the model to explain factors affecting the size of this cost. This research is enriched by providing data analysis using both static and dynamic models of panel data instead of either one as found in many previous studies. While this research has produced interesting findings and contributions to the existing literature, it has several limitations which can be regarded as a starting point for future research. The research was conducted within the specific definition of financial distress. As a result, it is uncertain whether the findings can be applied more broadly to other countries. With regards to the research in Malaysia, this research can also be expanded by examining the indirect financial distress costs from different group of companies. The relatively low overall explanatory power $\left(R^{2}\right)$ in this empirical paper 
reveals that there might be imperfect representations of theories in using proxies or the existence of other factors affecting FDC. Therefore, further research should extend and investigate the effects of other factors or use alternative proxies of variables.

\section{Corresponding Author}

Nor Arni Nazira Othman

Postgraduate Student Faculty of Business and Management Universiti Teknologi MARA, Perlis Branch Arau Campus, 02600 Arau, Perlis Malaysia

Email: Naziraarni334@gmail.com

\section{References}

Ahn, S. C., \& Schmidt, P. (1995). Efficient estimation of models for dynamic panel data. Journal of econometrics, 68(1), 5-27.

Andrade, G., \& Kaplan, S. N. (1998). How costly is financial (not economic) distress? Evidence from highly leveraged transactions that became distressed. The Journal of Finance, 53(5), 1443-1493.

Anwar, S., \& Sun, S. (2012). Trade liberalisation, market competition and wage inequality in China's manufacturing sector. Economic Modelling, 29(4), 1268-1277.

Arellano, M., \& Bond, S. (1991). Some tests of specification for panel data: Monte Carlo evidence and an application to employment equations. The review of economic studies, 58(2), 277-297.

Arellano, M., \& Bover, O. (1995). Another look at the instrumental variable estimation of error-components models. Journal of econometrics, 68(1), 29-51.

Brañas-Garza, P, Bucheli, M., and Garcia-Muñoz, T., (2011). Dynamic panel data: A useful technique in experiments. Universidad de Granada, Working papers, 10-22.

Butler, A. W., Keefe, M. O. C., \& Kieschnick, R. (2014). Robust determinants of IPO underpricing and their implications for IPO research. Journal of Corporate Finance, 27, 367-383.

Elali, W., \& Trainor, T. (2009). Advanced corporate finance: A practical approach. Pearson Addison Wesley.

Gertner, R., \& Scharfstein, D. (1991). A theory of workouts and the effects of reorganization law. The Journal of Finance, 46(4), 1189-1222.

Hoechle, D. (2007). Robust standard errors for panel regressions with cross-sectional dependence. Stata Journal, 7(3), 281.

Jensen, M. C. (1991). Corporate Control and The Politics Of Finance. Journal of Applied Corporate Finance, 4(2), 13-34.

Korteweg, A. G. (2007). The costs of financial distress across industries (Doctoral dissertation, The University of Chicago).

Lang, L., Poulsen, A., \& Stulz, R. (1995). Asset sales, firm performance, and the agency costs of managerial discretion. Journal of financial economics, 37(1), 3-37.

Lindsey, C., \& Sheather, S. (2010). Variable selection in linear regression. Stata Journal, 10(4), 650.

Makumi, A. N. (2013). Faculty of Health Sciences School of Public Health (Doctoral dissertation, School of Public Health, University of Witwatersrand Johannesburg).

Mehrara, M., \& Mohammadian, M. (2015). The Determinants of Gini Coefficient in Iran Based on Bayesian Model Averaging. Hyperion Economic Journal, 3(1), 20-28. 
Modigliani, F., \& Miller, M. H. (1958). The cost of capital, corporation finance and the theory of investment. The American economic review, 261-297.

Modigliani, F., \& Miller, M. H. (1963). Corporate income taxes and the cost of capital: a correction. The American economic review, 53(3), 433-443.

Opler, T. C., \& Titman, S. (1992). The indirect costs of financial distress. mimeo, Cox school of Business, Southern Methodist University.

Opler, T., \& Titman, S. (1993). The determinants of leveraged buyout activity: Free cash flow vs. financial distress costs. The Journal of Finance,48(5), 1985-1999.

Park, H. M. (2011). Practical guides to panel data modelling: a step-by-step analysis using stata. Public Management and Policy Analysis Program, Graduate School of International Relations, International University of Japan.

Pindado, J., \& Rodrigues, L. (2005). Determinants of financial distress costs. Financial Markets and Portfolio Management, 19(4), 343-359.

Pindado, J., Rodrigues, L., \& de la Torre, C. (2008). Estimating financial distress likelihood. Journal of Business Research, 61(9), 995-1003.

Shleifer, A., \& Vishny, R. W. (1992). Liquidation values and debt capacity: A market equilibrium approach. The Journal of Finance, 47(4), 1343-1366.

Tshitangano, F. (2010). Cost of financial distress model for JSE listed companies: a case of South Africa (Doctoral dissertation, University of Pretoria).

Wijantini (2007). A test of the relationship between Political connection and indirect costs of Financial Distress in Indonesia. Asian Academy of Management Journal of Accounting and Finance, 3(2), 61-81.

Zhang, P., \& Gan, S. (2010, August). Financial distress costs and ownership structure in listed companies. In Management and Service Science (MASS), 2010 International Conference on (pp. 1-5). IEEE. 